\title{
Editorial: Pan-European pension funds
}

\section{The dream}

There are two recurring themes in my dreams:

- I'm trying to get somewhere but never seem to make any progress

— I'm falling over a precipice.

You can see straight away that the prospect of pan-European pensions looks very much like the first of those two themes. In an ideal world a multinational would be able to have one pension scheme into which all its employees in all the countries in which it operates could belong - or at least in all EU countries - and they would all be subject to the same legislative treatment. Dream on.

\section{The problems}

There are only two problems - social security and tax - but what a couple of problems! Let's take social security first. There is a huge divergence between the level of social security paid between different EU member states. Ireland and the UK are very much at the lower end and countries like Italy and Greece at the upper. In fact, I was in Rome on one occasion when Italians took to the streets when the government there had suggested reducing it.

State benefit is a crucial element of total pension provision - and occupational pensions supplement State benefits. The result has been a highly-developed occupational pension system in the UK and other countries where there is a low level of basic State pension (Netherlands and Ireland). On the other hand, there has been very little need for supplementary pension provision in many other countries (like Italy and Greece) where the State provision leaves little need for top-ups.

The other problem is everyone's problem - tax. Clearly there is a need at least for consistent treatment between member states as far as tax is concerned. In many member states, tax is not made on employee and employer pension contributions, but the benefit received during retirement is taxable as earned income. However, in some jurisdictions tax is paid on employer contributions (being treated as a 'benefit in kind'), with the benefits usually being paid out tax free. Obviously this will be a problem where - as increasingly is the case employees spend a considerable part of their working life in one or more countries, but retire in another. An individual could find himself having paid tax on contributions paid into his pension scheme and then move into a jurisdiction where he pays tax on his retirement benefit as well: a real double whammy! Of course, for some lucky individuals the converse could happen - no tax on contributions and no tax on benefits. 


\section{The ways forward}

Fortunately, help may be at hand - and it may be coming from two directions at the same time. Is this like falling over a precipice - the second of my recurring dream themes? For more than ten years the European Commission has been working towards getting a pension fund directive adopted. Sir Leon Brittan started the ball rolling back in 1989 and most recently Mario Monti has been waving the flag. Over the years we have seen consultation documents, Green Papers, Communications and a failed directive.

Much to most people's surprise, the most recent development occurred in May 1998 when a Communication was issued. This was after all the Commissioners had resigned and were just carrying on in a caretaker capacity. Apart from the issues of prudential regulation of pension funds and removal of investment restrictions, with which this article is not concerned, the Communication deals primarily with:

- the transferability of supplementary pension rights

- the co-ordination of member states' tax arrangements relating to pensions and life assurance to facilitate labour mobility.

Mr Monti had been hoping to follow up the Communication with a draft directive around the end of the year. $\mathrm{He}$ is now sharing what used to be called DGXV - the area dealing with financial institutions and tax - with a Dutchman (Frits Bolkestein). However, I have it on good authority that it is $\mathrm{Mr}$ Bolkestein who will be taking forward the pension fund work. Since I have already made it clear that the Dutch have a

well-developed pension fund market, we can expect him to be enthusiastic about the development of pension funds
Europe-wide.

However, harmonisation of tax is a tricky subject and not every member state will go for it - certainly the UK appears to be opposed.

I do not see social security differences throughout the EU as a major obstacle to pan-European pension funds. I imagine that most multinationals would want to be aiming at a target overall benefit (State plus occupational provision) of, say, two-thirds of final remuneration for a full career. For those people who spend all their working lives in one country the benefit would be clear cut. For those who go from country to country, the benefit provided by the panEuropean pension fund would be more or less, depending on how small or great the State benefits were in the country of retirement.

But in May 1998 another stone rippled the pool. Jessica Safir, a Swedish national, took out a life policy with a UK insurer. Had she taken out her policy with a Swedish insurer, the insurer would have accounted for tax on her contributions. In order to try to achieve a tax neutral situation, Sweden imposes a special tax where policies are taken out with overseas companies - although an exemption (or partial exemption) can be granted if the non-Swedish insurer pays local tax comparable to the Swedish rate. Ms Safir appealed against the fact that full exemption was not granted on the premiums to her policy.

The case eventually reached the ECJ. The ECJ found that the method of imposing the tax where the insurer was not Swedish was so complicated as to deter an individual from taking out insurance with a non-Swedish company. This, the ECJ considered, was discriminatory. Provided there is no fiscal vacuum, the ECJ considers that impediments to cross-border insurance services are unacceptable. 
Various lawyers, consultants and multinationals' eyes glinted when they read about this case - could the same thought processes not be read across to the different tax treatment meted out to occupational pension scheme members who hop from country to country and wish to stay in their home country scheme? The latest thinking is that a test case should be brought so that the ECJ can decide. The intention is that a multinational will set up a pan-European pension fund in a particular member state for all of its EU employees.

As I understand it, the particular employer in each member state will then seek from the appropriate national tax authorities the tax privilege that would have been available had the fund been set up in the country in which that particular employer is based. If the appropriate national tax authority does not agree to the granting of the appropriate tax privileges then, depending upon the way in which the arrangement is set up, either the national tax authorities will bring a case against the employer or vice versa.
The key to success is, of course, sufficient funding of the venture. The case would have to go through the national courts before it ever got to the ECJ and the whole affair would prove extremely expensive. Of course, it would also take a long time.

Nevertheless, it is thought that this would still be a quicker route than trying to achieve tax harmonisation through a directive. (At present taxation measures require the unanimity of all member states.)

\section{Does anyone want it anyway?}

I suspect there is little demand for pan-European pension funds at present. However, whichever route one goes down, it will be some years before there is a solution. Maybe a vehicle will be in place by the time demand for it appears. In the meantime, it is back to my dream theme number one - we're not getting anywhere very fast.

Colin Steward, Secretary General of EURACS

\section{Erratum}

In the article by Dr Julian Farrand, 'Resolving pension disputes - An Ombudsman's view', published in Journal of Pensions Management, Volume 4, Issue 4, pp316-32, references 38 to 48 were incorrectly numbered. Please note that on p328 reference 38 should read 39, 39 should read 40 and so on to reference 48 . 